\title{
Effect of Neisseria gonorrhoeae on human and rabbit oviducts
}

\author{
D. TAYLOR-ROBINSON, SUSAN WHYTOCK, C. J. GREEN, AND F. E. CARNEY JR*. \\ M.R.C. Clinical Research Centre, Watford Road, Harrow, Middlesex H.A1 $3 U \mathcal{F}$
}

With the single exception of the chimpanzee, Neisseria gonorrhoeae is specific for its human host. We have previously shown, however, that gonococci grow in organ cultures other than those of human origin, although the arrest of epithelial cell ciliary activity occurs most rapidly in human oviduct (Fallopian tube) cultures (Carney and TaylorRobinson, 1973). To determine the mechanism by which the organisms damage the epithelium and to investigate the reasons for host specificity, we have undertaken a comparative study of the effect of $N$. gonorrhoeae on organ cultures of Fallopian tube and rabbit oviduct. In addition, some experiments were performed on rabbits in vivo. The main approach has been to examine tissues by electron microscopy.

\section{Material and methods}

\section{NEISSERIA GONORRHOEAE}

A previously described strain of $N$. gonorrhoeae was used (Carney and Taylor-Robinson, 1973). This was resistant to streptomycin and was of colonial type 4 . The organisms were grown in brain-heart infusion (Difco) with 20 per cent. heat-inactivated foetal calf serum containing 100 units streptomycin $/ \mathrm{ml}$. and $0.05 \mathrm{M}$ HEPES buffer. The $\mathrm{pH}$ of the medium was adjusted to $7 \cdot 2$. Chocolate agar was used for growth on solid medium.

\section{ORGAN CULTURES}

Fallopian tube organ cultures were prepared, maintained, and observed for ciliary activity as described by Carney and Taylor-Robinson (1973). Oviducts were obtained aseptically from white hybrid rabbits weighing approximately $3 \mathrm{~kg}$. These animals were anaesthetized by injecting them intramuscularly with a mixture of $0.2 \mathrm{mg}$. fentanyl base $/ 10 \mathrm{mg}$. fluanisone, and they were maintained on nitrous oxide and oxygen in equal proportions at a

Received for publication December 24, 1973

Address for reprints: D. Taylor-Robinson, as above

$\star$ Visiting worker from the Department of Obstetrics and Gynecology,

Shands Teaching Hospital, Gainesville, Florida 32601, U.S.A. flow rate of 2 litres per min. Organ cultures prepared from the oviducts were handled in the same way as those of human origin. In addition, rabbits were anaesthetized as described and gonococci suspended in Eagle's medium were inoculated directly into the oviducts, some of which had been ligated at both fimbrial and uterine ends. At intervals the oviducts were aspirated for bacteriological culture and they were removed after 5 days for electron microscopy.

Some organ pieces were placed in saline $(\mathrm{pH} 7 \cdot 2)$ at room temperature for $48 \mathrm{hrs}$ in order to damage them. This treatment stopped ciliary activity. Some of the same pieces were further treated by soaking them in 0.05 per cent. saponin in saline for $1 \mathrm{~min}$.; they were washed three times in Eagle's medium before use.

\section{ELECTRON MICROSCOPY}

Infected and uninfected human and rabbit oviduct organ cultures were prepared for electron microscopy in the following way. The cultures were wholly immersed in 3 per cent. glutaraldehyde in $0 \cdot 15 \mathrm{M}$ phosphate buffer for $45 \mathrm{~min}$. at $4^{\circ} \mathrm{C}$., followed by 1 per cent. osmium tetroxide in Millonig's buffer (Millonig, 1961) for $1 \mathrm{hr}$ at $4^{\circ} \mathrm{C}$. After fixation, small pieces of mucosa were dissected from the cultures. These were washed in cold distilled water, dehydrated in increasing concentrations of acetone, and embedded in epoxy resin (Araldite), each portion being supported on a thin slice of 2 per cent. agar in the resin. Thick sections $(1-2 \mu)$ of the tissue were cut on an ultramicrotome, stained with 1 per cent. toluidine blue in 1 per cent. borax, and examined by light microscopy to locate the tubal epithelium in the Araldite block. Thin sections of epithelium $(600-700 \AA)$ were stained in saturated uranyl acetate in 50 per cent. acetone for $30 \mathrm{~min}$., followed by lead citrate (Reynolds, 1963) for $2 \mathrm{~min}$., and then very lightly coated with a carbon film after staining. The stained sections were examined in a Philips 300 electron microscope at $60 \mathrm{KV}$.

\section{Results}

MULTIPLICATION OF N. GONORRHOEAE

Gonococci inoculated into human and rabbit oviduct organ cultures increased in number in the supernatant media (Table I). Growth was more rapid 
in human than in rabbit cultures and the highest number of organisms attained was usually about 10fold more in the experiments with human tissue. As noted previously (Carney and Taylor-Robinson, 1973), organisms suspended in medium without tissue died within $24 \mathrm{hrs}$, but they persisted for a week or longer in the rabbit oviduct cultures.

Gonococci were introduced also into the oviducts of rabbits under anaesthesia, in some cases after the tubes had been ligated to form closed chambers (Table II). There was no evidence of multiplication and, furthermore, the organisms were not recovered when the oviducts were aspirated between 2 and 5 days after inoculation.

\section{CILIARY ACTIVITY}

This stopped 2 to 4 days after introducing gonococci into Fallopian tube organ cultures (Table I), while the cilia of uninoculated cultures continued to beat for a longer period. In contrast, the ciliary activity of infected rabbit oviduct organ cultures stopped at about the same time as that of uninoculated cultures; at the most, activity ceased 1 day before that of the control cultures.

Rabbit oviducts which had been infected in vivo (Table II) were found sometimes to be distended. However, this was observed also when the tubes were inoculated with Eagle's medium only. Despite dis- tension, tubes removed at various times, between 5 and 15 days after inoculation, were found to have vigorous ciliary activity.

\section{ELECTRON MICROSCOPY}

\section{Fallopian tube organ cultures}

The appearance of the epithelium of an uninoculated tube a few hours after organ culture preparation is shown in Fig. 1. The luminal surface of all cells has microvilli but only some of the cells are ciliated. Most of the non-ciliated cells are secretory cells. Organ cultures, which were mostly those of Expt. 2 (Table I), were examined at various times after inoculation. Gonococci were seen attached to the microvilli and surface of non-ciliated cells (Fig. $2 a, b, c$ ) with entry first detectable after $20 \mathrm{~min}$. (Fig. $2 d$ ). In older cultures (Fig. $2 b, c$ ), many bacteria were seen attached to non-ciliated cells and either in the process of entering or being released from them. A decrease in the staining intensity of the cytoplasm of ciliated cells (Fig. 3) was seen $16 \mathrm{hrs}$ after infection. This appearance, usually associated with cell death, was observed 1 to 2 days before there was a detectable decrease in ciliary activity. Ciliated cells which are undoubtedly necrotic were seen in the later stages of infection; such a dead cell, seen after $64 \mathrm{hrs,} \mathrm{is} \mathrm{shown}$ in Fig. 4. In addition, organisms were seen deep

TABLE I Growth and effect of N. gonorrhoeae in human and rabbit oviduct organ cultures

\begin{tabular}{|c|c|c|c|c|c|c|c|c|c|c|c|c|}
\hline \multirow{3}{*}{$\begin{array}{l}\text { Experiment } \\
\text { no. }\end{array}$} & \multirow{3}{*}{$\begin{array}{l}\text { Origin of } \\
\text { tissue }\end{array}$} & \multicolumn{9}{|c|}{ No. of organisms $\left(\times 10^{5} / \mathrm{ml}\right.$. $)$ in medium on day } & \multicolumn{2}{|c|}{$\begin{array}{l}\text { Average duration (days) of ciliary } \\
\text { activity in }\end{array}$} \\
\hline & & 0 & 1 & 2 & 3 & 4 & 5 & 6 & 7 & 8 & & \\
\hline & & & & & & & & & & & Infected cultures & Uninfected cultures \\
\hline $\begin{array}{l}1 \\
2\end{array}$ & $\begin{array}{l}\text { Human } \\
\text { Human }\end{array}$ & $\begin{array}{l}0.02 \\
10\end{array}$ & $\begin{array}{l}1,000 \\
600\end{array}$ & 500 & & & & & & & $\begin{array}{l}2 \\
3 \cdot 7\end{array}$ & $\begin{array}{l}>5 \\
>5\end{array}$ \\
\hline $\begin{array}{l}3 \\
4 \\
5\end{array}$ & $\begin{array}{l}\text { Rabbit } \\
\text { Rabbit } \\
\text { Rabbit }\end{array}$ & $\begin{array}{l}0 \cdot 7 \\
7 \\
90\end{array}$ & $\begin{array}{l}0.4 \\
90 \\
200\end{array}$ & $\begin{array}{l}60 \\
80\end{array}$ & $\begin{array}{l}84 \\
10\end{array}$ & & 3 & $\begin{array}{l}20 \\
30\end{array}$ & 5 & 1 & $\begin{array}{l}8 \\
7 \\
6 \cdot 4\end{array}$ & $\begin{array}{l}8 \cdot 7 \\
8 \cdot 7 \\
7\end{array}$ \\
\hline
\end{tabular}

TABLE II Effect of inoculating N. gonorrhoeae into rabbit oviducts in vivo

\begin{tabular}{|c|c|c|c|c|c|c|c|c|c|}
\hline \multirow{3}{*}{$\begin{array}{l}\text { Experiment } \\
\text { no. }\end{array}$} & \multirow{3}{*}{$\begin{array}{l}\text { Tube } \\
\text { tied }\end{array}$} & \multirow{3}{*}{ Type of control } & \multirow{2}{*}{\multicolumn{2}{|c|}{ Number of organisms }} & \multicolumn{4}{|c|}{ Swelling of } & \multirow{3}{*}{$\begin{array}{l}\text { Ciliary activity of infected } \\
\text { tube after (days) }\end{array}$} \\
\hline & & & & & \multicolumn{2}{|c|}{ Infected } & \multicolumn{2}{|c|}{ Control } & \\
\hline & & & Proctatated & (days) & Tube & Horn & Tube & Horn & \\
\hline $\begin{array}{l}1 \\
2 \\
3 \\
4 \\
5 \\
6\end{array}$ & $\begin{array}{l}- \\
- \\
+ \\
+ \\
+\end{array}$ & $\begin{array}{l}\text { Nil } \\
\text { Em } \\
\text { Nil } \\
\text { Tube tied only } \\
\text { Tube tied and Em } \\
\text { Tube tied and Em } \\
\text { with heat killed } \\
\text { gonococci }\end{array}$ & $\begin{array}{l}2 \times 10^{7} \\
2 \times 10^{8} \\
8 \times 10^{8} \\
4 \times 10^{8} \\
2 \times 10^{5} \\
2 \times 10^{5}\end{array}$ & $\begin{array}{l}\text { Nil (5) } \\
\text { Nil (2) } \\
\text { Nil (3) } \\
\text { Nil (5) } \\
\text { Nil (4) } \\
\text { Nil (4) }\end{array}$ & $\begin{array}{l} \pm \\
- \\
- \\
+ \\
+ \\
+\end{array}$ & $\begin{array}{l}+ \\
\pm \\
- \\
- \\
- \\
-\end{array}$ & $\begin{array}{l}\overline{+} \\
+\end{array}$ & $\begin{array}{l}+ \\
- \\
-\end{array}$ & $\begin{array}{l}+(5) \\
N T \\
+(10) \\
+(9) \\
+(15) \\
+(15)\end{array}$ \\
\hline
\end{tabular}




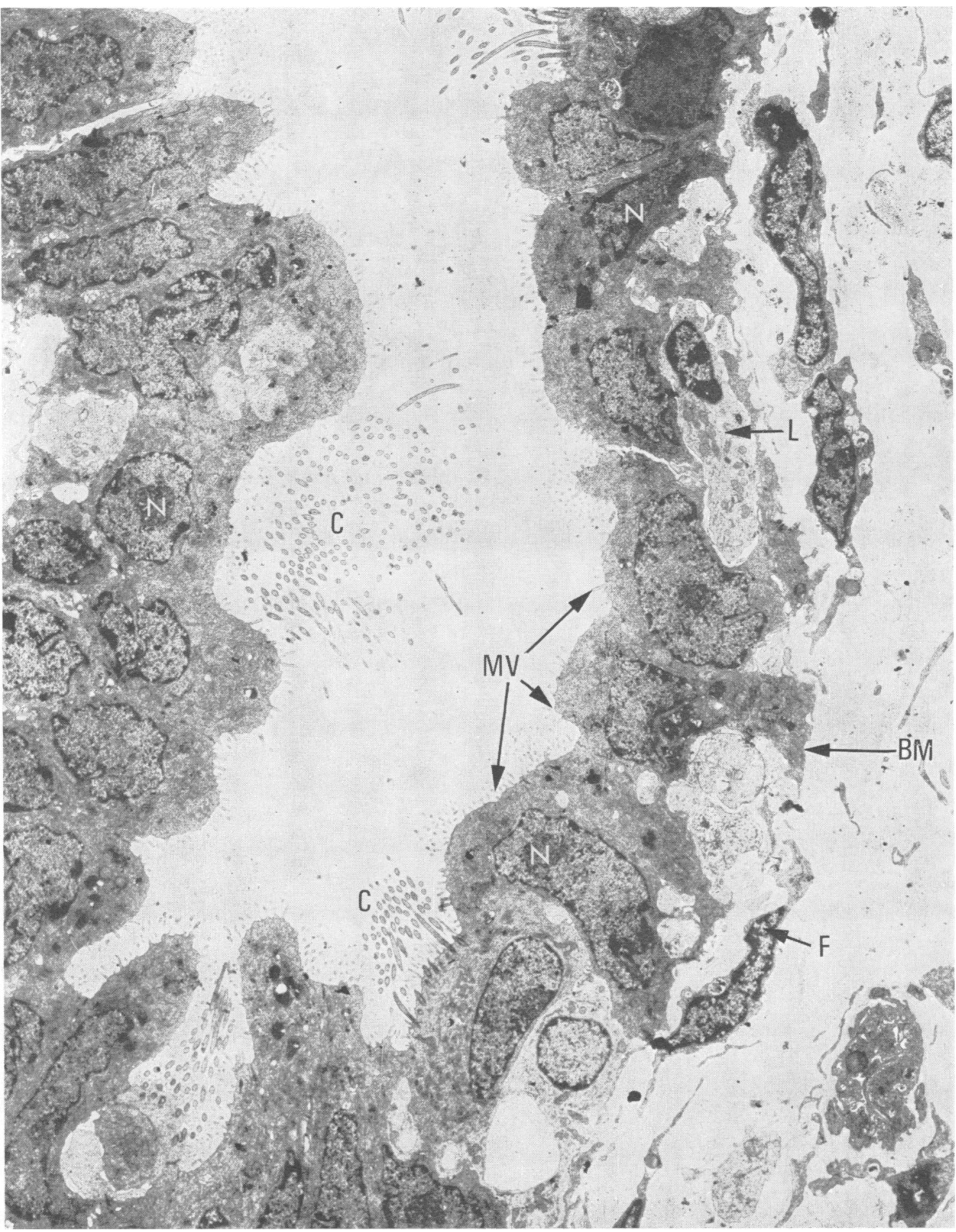

FIG. 1 Fallopian tube organ culture less than 24 hrs after preparation. $\times 3,204 . C$, cilia; $M V$, microvilli; $B M$, basement membrane; $F$, fibrocyte; $L$, probable lymphocyte; $N$, nucleus 

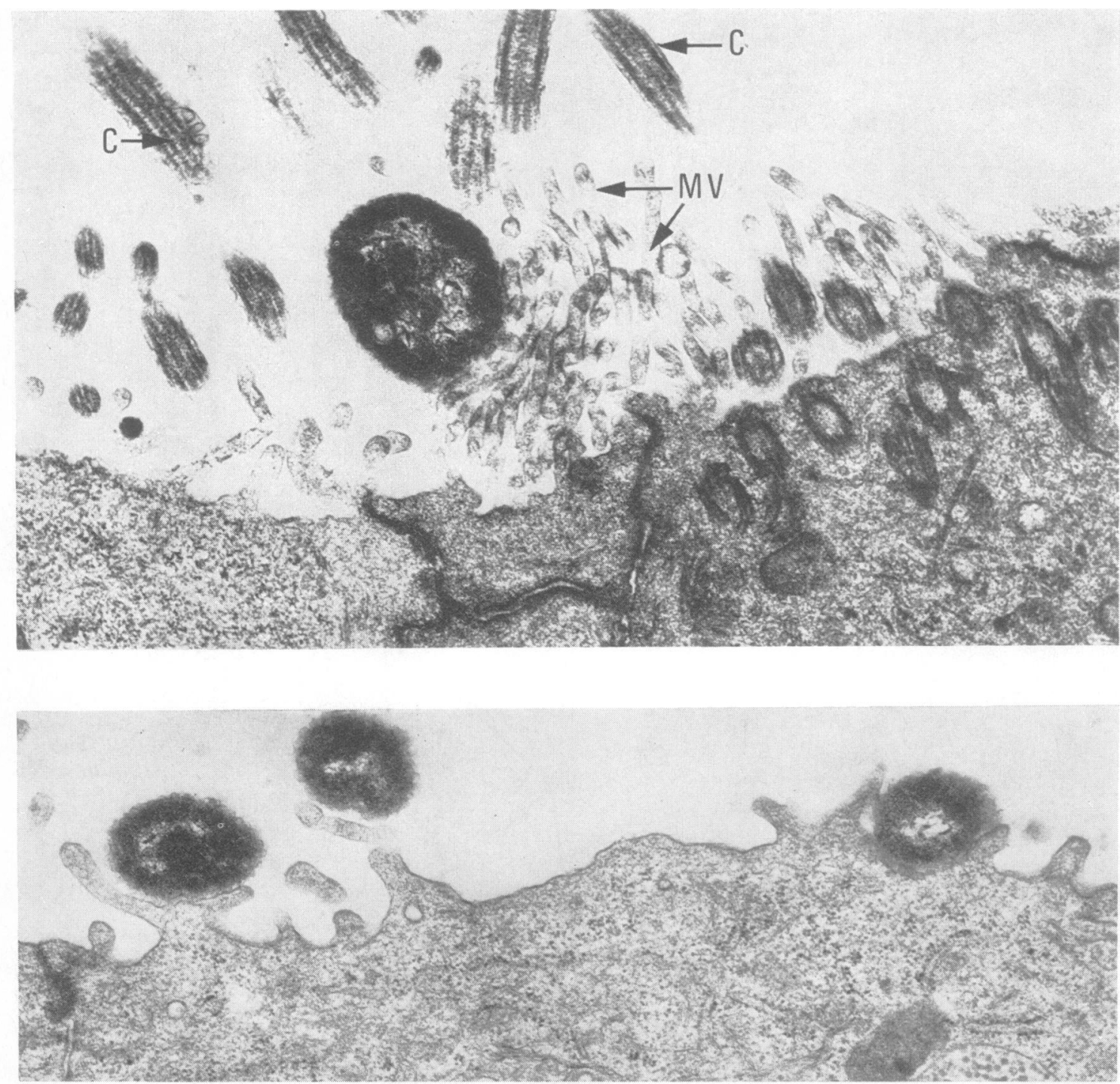

(c)
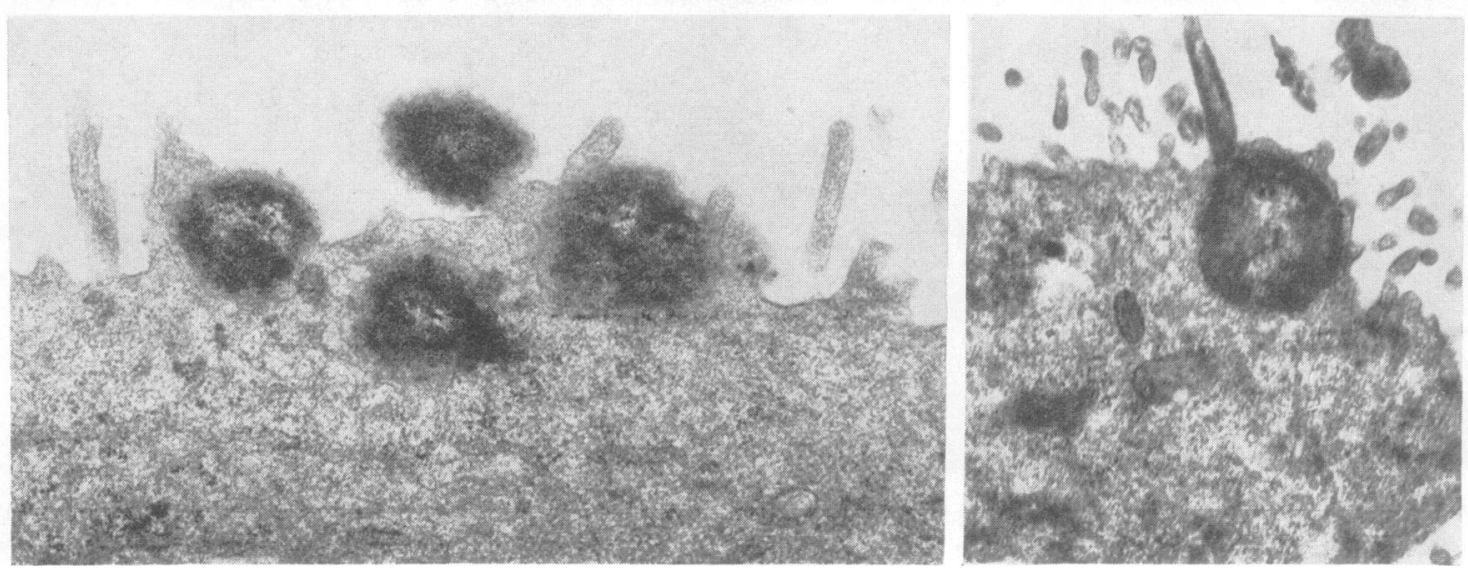


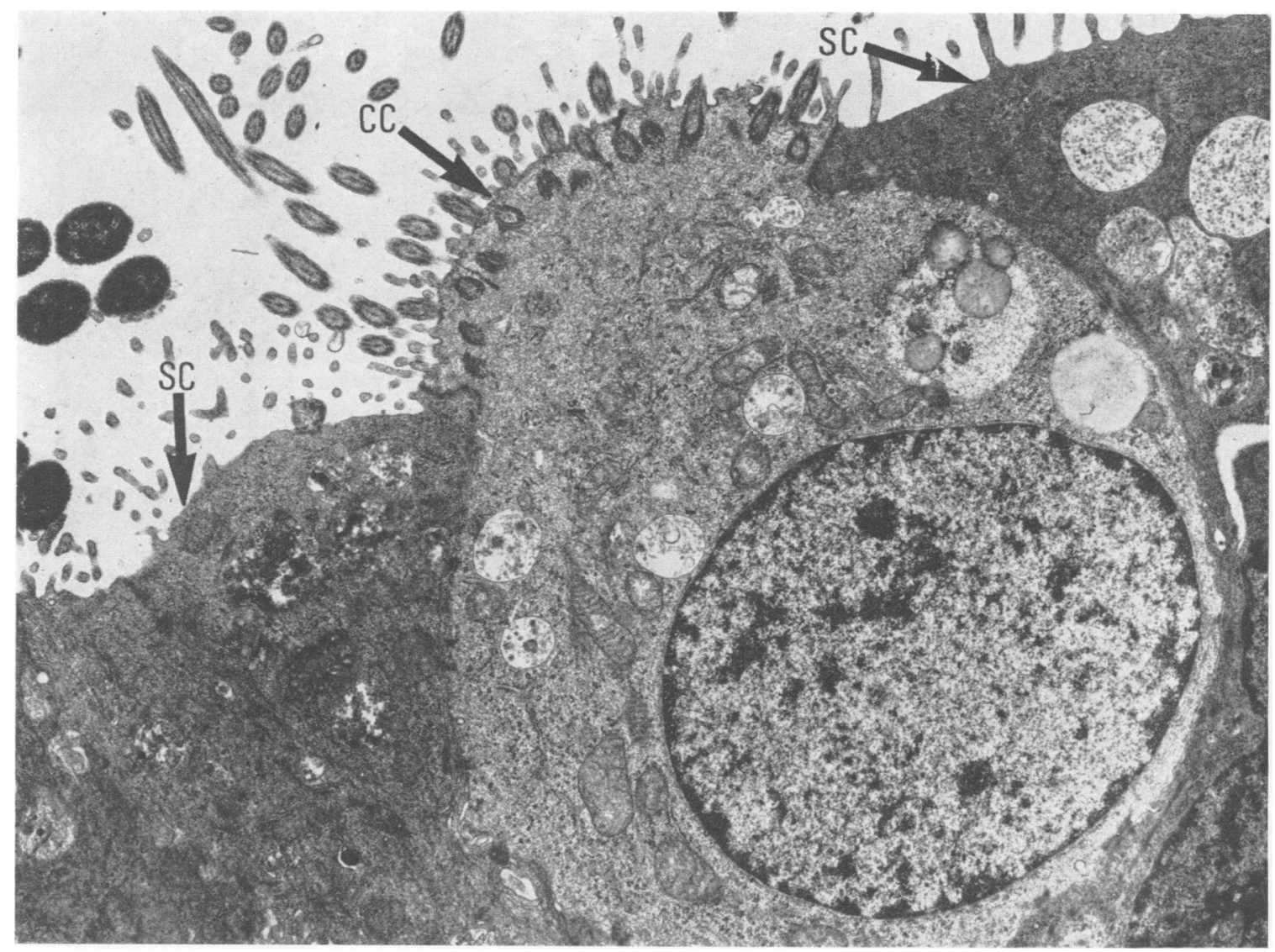

FIG. 3 Fallopian tube organ culture 16 hrs after infection. Attachment of gonococci to microvilli and decrease in the staining intensity of the cytoplasm of a ciliated cell. $\times 7,022 . S C$, secretory cell; CC, ciliated cell

within the cytoplasm of adjacent secretory cells, but never within identifiable ciliated cells. At this time large numbers of organisms were seen both within (Figs 5 and 6) and between (Fig. 6) cells, and there was evidence of multiplication as some of the organisms were apparently undergoing binary fission. Uninoculated Fallopian tubes after the same period of time in culture were normal in appearance (Fig. 7).

\section{Rabbit oviduct organ cultures}

Although gonococci multiplied in the medium of rabbit cultures, there was no evidence that they attached to the epithelial cells or entered them. Thus, the epithelium of cultures (Expt. 5, Table I) examined 1,2, and 3 days after inoculation appeared normal. Likewise, cultures of Expt. 3 (Table I) 7 days after inoculation appeared normal (Fig. 8) except for the occurrence of vacuoles which were seen also in uninoculated cultures after this time.

Rabbit oviducts infected in vivo

An oviduct taken from a rabbit 5 days after the tube had been inoculated in vivo (Expt. 1, Table II) was

FIG. 2 Fallopian tube organ cultures (a) Attachment of gonococcus to microvilli after 20 min. incubation at $37^{\circ} \mathrm{C} . \times 27,588 . C$, cilia; $M V$, microvilli

(b) Attachment of gonococci to secretory cells after $40 \mathrm{hrs} . \times 25,650$

(c) Attachment of gonococci to secretory cells after 16 hrs. $\times 23,461$.

(d) Entry of gonococcus into secretory cell after $20 \mathrm{~min} . \times 15,960$ 


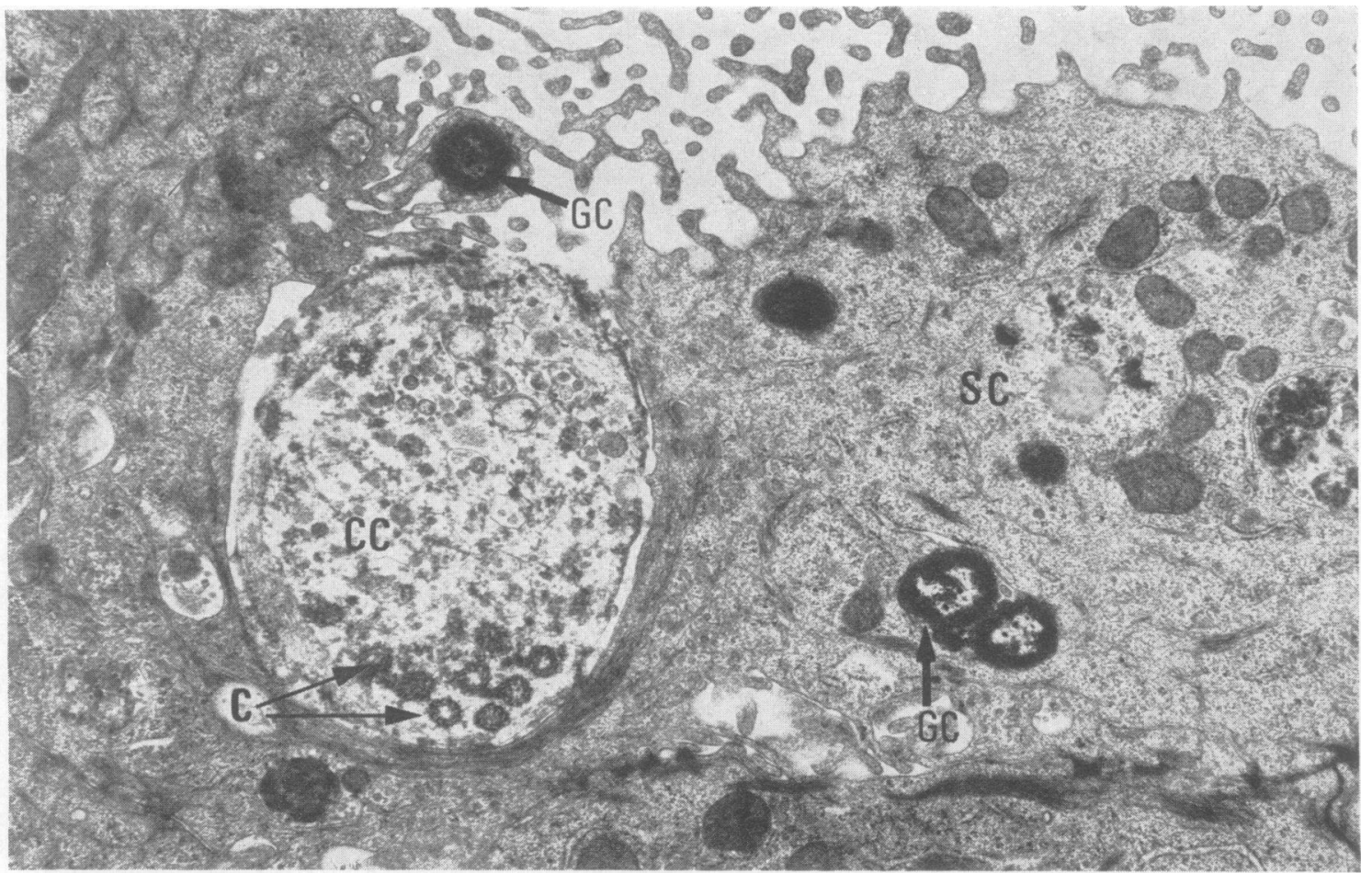

FIG. 4 Fallopian tube organ culture 64 hrs after infection. Death of ciliated cell and gonococci deep within a secretory cell. $\times 13,406$. $C$, cilia; SC, secretory cell; CC, ciliated cell; $G C$, gonococcus

examined. No gonococci were seen and the epithelial cells showed no signs of infection.

Damaged organ cultures infected with $\mathrm{N}$. gonorrhoeae Organ cultures of Fallopian tube and rabbit oviduct were damaged by keeping them in saline and some by additional treatment with saponin before infection. In Fallopian cultures, there were initially $5 \times 10^{4}$ gonococci $/ \mathrm{ml}$. of culture medium and these increased to $7 \times 10^{8} / \mathrm{ml}$. after $51 \mathrm{hrs}$ ' incubation at $37^{\circ} \mathrm{C}$. However, examination by electron microscopy after $64 \mathrm{hrs}$ did not reveal organisms attached to, within, or between the epithelial cells of the treated cultures of either human or rabbit origin.

\section{Discussion}

Our observations on the effects of gonococci on human and rabbit oviducts are summarized in Table III. Similar observations on the attachment of gonococci to urethral epithelial cells have been reported by Ward and Watt $(1972,1973)$. In the later stages of Fallopian tube infection we saw clusters of organisms between and within epithelial cells. Whether this was due to their multiplication within the tissues or to infiltration and gradual accumulation within a disintegrating tissue was difficult to assess. If the latter were the case, however, gonococci should have been found within Fallopian tube tissues which we had damaged before infection and, indeed, in

TABLE III Summary of effects of N. gonorrhoeae on human and rabbit oviducts

\begin{tabular}{llll}
\hline $\begin{array}{l}\text { Type of culture } \\
\text { Fallopian tube organ culture }\end{array}$ & $\begin{array}{l}\text { Multiplication } \\
\text { of gonococci }\end{array}$ & $\begin{array}{l}\text { Electron microscope observations } \\
\text { Attachment of }\end{array}$ & $\begin{array}{l}\text { Presence of } \\
\text { ciliary activity }\end{array}$ \\
$\begin{array}{l}\text { Rabbit oviduct organ culture } \\
\text { Damaged human or rabbit oviduct organ }\end{array}$ & + & + & + \\
$\begin{array}{l}\text { culture } \\
\text { Rabbit oviduct in vivo }\end{array}$ & + & - & - \\
\hline
\end{tabular}




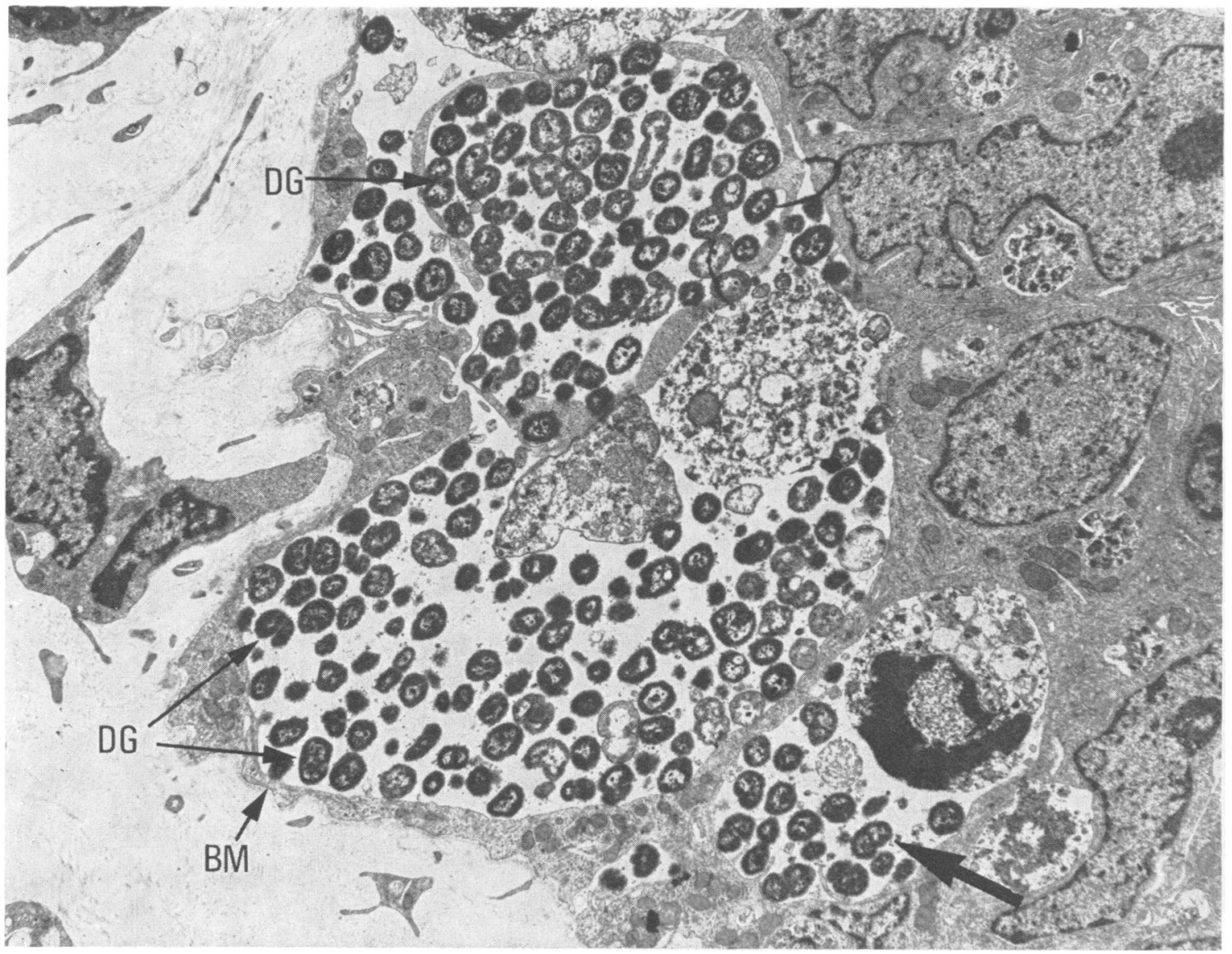

FIG. 5 Fallopian tube organ culture $64 \mathrm{hrs}$ after infection. Clusters of gonococci enclosed by the basement membrane. $\times 4,788 . D G$, dividing gonococcus; BM, basement membrane. Arrow indicates former cell site where gonococci have multiplied. The cell debris is confined to one end of the space

rabbit oviducts which had been incubated for relatively long periods of time. The fact that gonococci were never found in such tissues, despite their presence in the culture media, suggests that their presence in tissues of human origin was due to specific attachment to the cells followed by penetration and multiplication within them. The damage to secretory cells in this way presumably affected neighbouring ciliated cells and brought about the changes in ciliary activity. The destruction of cells by organisms growing within them may not be the only factor, however, in loss of ciliary activity, as damage to ciliated cells was observed (Fig. 3) before there was extensive uptake of organisms by secretory cells. A toxin could be responsible, at least in part, for some of the pathological changes and we have preliminary evidence for the existence of a toxin in the supernatant medium of infected cultures.

The virulence of gonococci of colonial type 1 has been attributed to their possession of surface pili (Swanson, Kraus, and Gotschlich, 1971). In this connection, Punsalang and Sawyer (1973) noted that type 1 gonococci, attached to human buccal epithelial cells, agglutinated various mammalian erythrocytes including those of the rabbit, and resisted phagocytosis by polymorphonuclear leucocytes, while type 4 gonococci did not react in these ways. It is interesting, therefore, that non-pilated type 4 organisms are capable of attaching to Fallopian tube secretory epithelial cells. It may be that more of the pilated type 1 organisms will attach and so initiate greater damage. The abilty of type 4 gonococci 


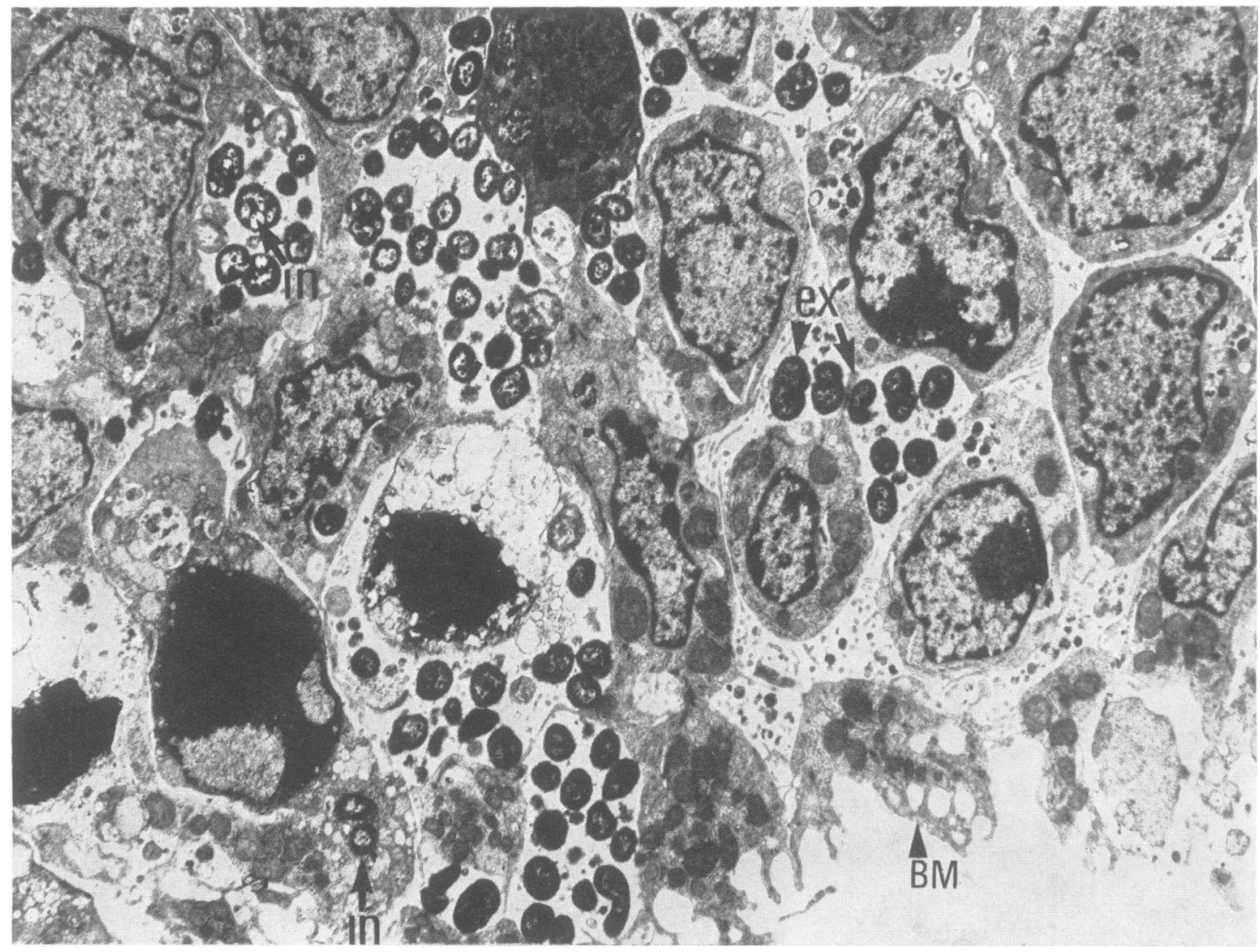

FIG. 6 Fallopian tube organ culture 64 hrs after infection. Gonococci inside and between cells. $\times 4,788$. $B M$, basement membrane; in, intracellular gonococci; ex, extracellular gonococci

to attach to human oviduct cells and not to rabbit oviduct cells, even though they multiplied in the media of rabbit oviduct organ cultures, may be one of the factors concerned in host specificity. The reason for lack of adherence to rabbit cells is not clear. It is possible that mucus on the rabbit epithelial cell surface played a part, since rabbit oviduct secretory cells often appeared to be more active than those of Fallopian tubes in that they contained many mucus-secreting vacuoles. Alternatively, rabbit cells in organ culture may lack specific receptors, at least for type 4 organisms. Whether type 1 gonococci behave in the same way is not yet known. There seems no doubt, however, that such organisms attach to and apparently penetrate cells of non-human origin, e.g. mouse fibroblasts and monkey kidney cells (Waitkins and Flynn, 1973), when they are kept as conventional cell cultures. Cells in organ culture, however, may behave in a different manner.
The virtues of the organ culture system need not be stressed. Our experiments, however, indicate that it is unwise to assume that events which occur in organ culture necessarily reflect those which occur in vivo. Although gonococci multiplied in the medium of rabbit oviduct organ cultures, growth was not detected when the organisms were introduced in vivo into oviducts which had been tied at both ends. Indeed, the organisms disappeared rapidly. We had

FIG. 7 Uninfected Fallopian tube organ culture after $64 \mathrm{hrs}$. Epithelium appears normal. $\times$ 5,814. BM, basement membrane; $C C$, ciliated cell; SC, secretory cell

FIG. 8 Rabbit oviduct organ culture 7 days after inoculation of gonococci. Numerous empty vacuoles $(V)$ appear in all infected and uninfected organ cultures after a few days. $\times 2,492$ 

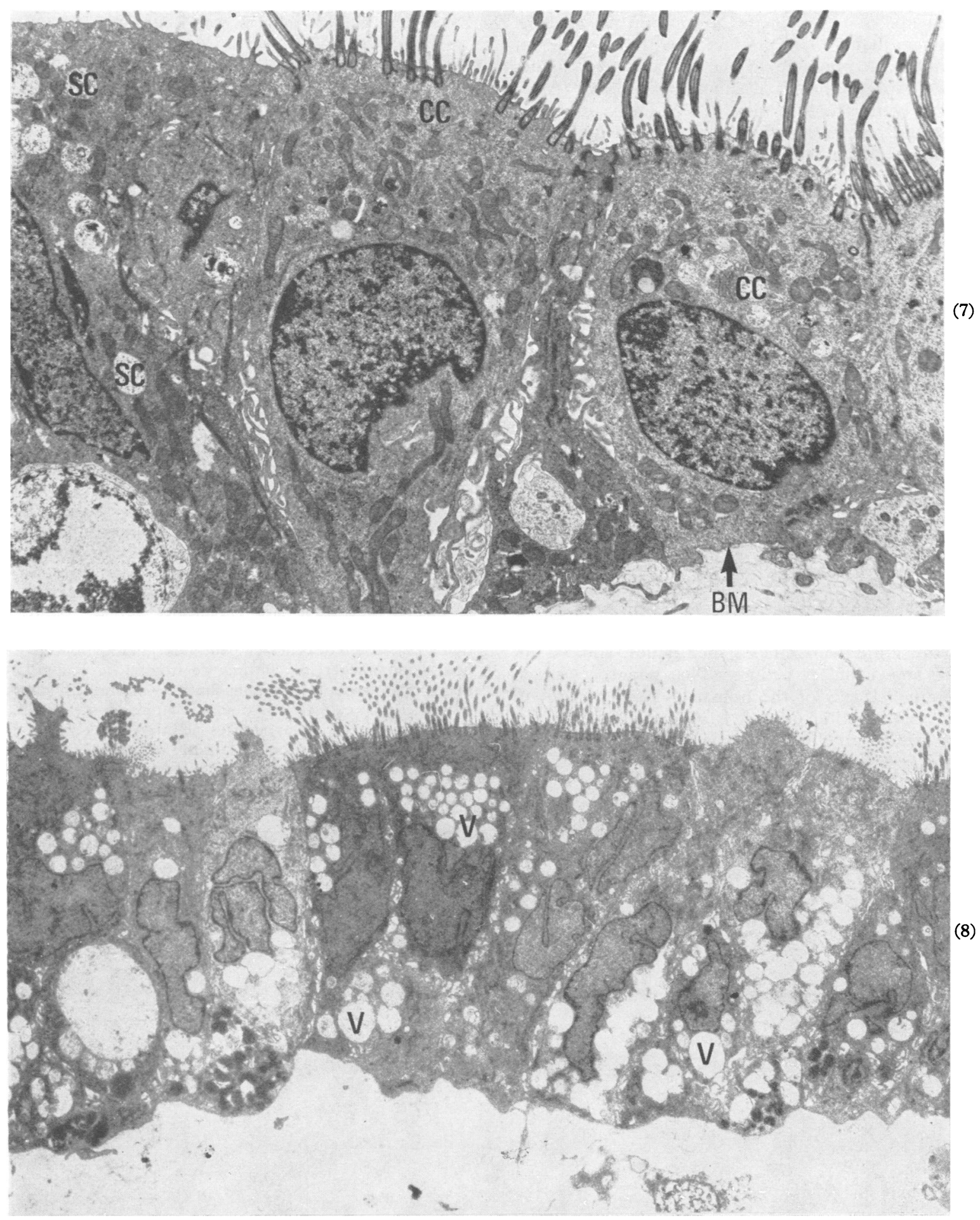
anticipated that they might multiply in the artificial chambers that we had produced, as they do in inert chambers incorporated in the subcutaneous tissues of rabbits and other small laboratory animals (Arko, 1972; Flynn and Waitkins, 1973). Clearly, immunological factors must play a major part in preventing multiplication in rabbit oviducts in vivo.

\section{Summary}

$N$. gonorrhoeae of colonial type 4 multiplied in Fallopian tube organ cultures and stopped ciliary activity within 4 days. Electron microscopy revealed gonococci attached to non-ciliated secretory cells, and their entry into these cells was first detectable after $20 \mathrm{~min}$. 2 to 3 days after infection, large clusters of organisms were seen both within and between cells. Gonococci were not found, however, in tissues that had been damaged before infection. This suggests that specific attachment of the organisms to secretory cells, followed by entry and multiplication within them, may be important in causing damage to the Fallopian cultures. In contrast, although gonococci multiplied in the media of rabbit oviduct cultures, there was no evidence that they attached to the epithelial cells or entered them. Furthermore, loss of ciliary activity was not significantly faster in infected rabbit organ cultures than in uninfected ones. Gonococci, inoculated in large numbers into oviducts of rabbits under anaesthesia, died rapidly and did not cause loss of ciliary activity. That gonococci attach to epithelial cells of the human oviduct but not to those of the rabbit oviduct is suggested as a significant factor in this host specificity exhibited by N. gonorrhoeae.

We thank Mr. A. M. Fisher and Mr. I. R. McFadyen (Northwick Park Hospital) for providing Fallopian tubes, Dr. R. Dourmashkin for helpful discussion, and Mr. G. F. Heath for excellent technical assistance.

\section{References}

ARKo, R. J. (1972) Science, 177, 1200
CARney, F. E., JR., and TAYloR-Robinson, D. (1973) Brit. F. vener. Dis., 49, 435

FlynN, J., and WAITKINS, S. A. (1973) Ibid., 49, 432

Millonig, G. (1961) f. appl. Physics, 32, 1637

Punsalang, A. P., JR., and SAwyer, W. D. (1973) Infect. and Immun., 8, 255

Reynolds, E. S. (1963) f. Cell Biol., 17, 208

Swanson, J., KraUs, S. J., and GotsChlich, E. C. (1971) f. exp. Med., 134, 886

WartKins, S. A., and FlYNN, J. (1973) f. med. Microbiol., 6, 399

WARD, M. E., and WATT, P. J. (1972) f. infect. Dis., 126, 601

—— (1973) Brit. med. F., 1, 485

Effet de Neisseria gonorrhoeae sur les oviducts de l'homme et du lapin

\section{SOMMAIRE}

$N$. gonorrhoeae, type de colonie 4, se multiplie dans les cultures de tissu de trompe de Falloppe et arrête l'activité ciliaire en quatre jours. La microscopie électronique décela des gonocoques fixés sur les cellules sécrétoires non ciliaires et leur entrée dans ces cellules put déjà être détectée après 20 minutes. Deux à trois jours après l'infection, on a vu de larges amas d'organismes à la fois à l'intérieur et entre les cellules. Cependant, les gonocoques ne furent pas trouvés dans les tissus qui avaient été altérés avant l'infection. Ceci fait penser que la fixation spécifique des organismes sur les cellules sécrétoires, suivie par leur pénétration et leur multiplication à l' intérieur de celles-ci, peut jouer un rôle important pour endommager les cultures de trompe de Falloppe. Par contre, quoique les gonocoques se multiplient dans les milieux de culture d'oviducts de lapin, on n'a pas de preuves qu'ils se fixent sur les cellules épithéliales ou qu'ils y pénètrent. En outre, la perte de l'activité ciliaire ne fut pas significativement plus rapide dans les cultures d'organes de lapins infectés que dans celles qui ne l'étaient pas. Les gonocoques, inoculés en grand nombre, sous anesthésie, dans les oviducts de lapin moururent rapidement et n'entraînèrent pas de perte de l'activité ciliaire. On pense que le fait que les gonocoques se fixent sur les cellules épithéliales de l'oviduct humain mais non sur celles de l'oviduct de lapin, constitue un facteur significatif de la spécificité de l'hôte vis-à-vis de $N$. gonorrhoeae. 